\title{
Assessment of the nutritive value of corn stover and king grass in complete feed on Ongole steer calves productivity
}

\author{
Ronny Agustinus Victor Tuturoong D, Sjenny Sutryaty Malalantang and Sony Arthur Ely Moningkey \\ Department of Animal Feed and Nutrition, Faculty of Animal Science, Sam Ratulangi University, Manado 95115, \\ North Sulawesi, Indonesia. \\ Corresponding author: Ronny Agustinus Victor Tuturoong, e-mail: ronny.tuturoong@yahoo.com \\ Co-authors: SSM: sjennymalalantang@unsrat.ac.id, SAEM: sonnymoningkey@gmail.com \\ Received: 03-11-2019, Accepted: 13-02-2020, Published online: 28-04-2020
}

doi: www.doi.org/10.14202/vetworld.2020.801-806 How to cite this article: Tuturoong RAV, Malalantang SS, Moningkey SAE (2020) Assessment of the nutritive value of corn stover and king grass in complete feed on Ongole steer calves productivity, Veterinary World, 13(4): 801-806.

\begin{abstract}
Aim: This study aimed to assess the nutritional values of corn stover and king grass (Pennisetum purpupoides) in complete feed on the productivity of male Ongole steer calves.

Materials and Methods: This study was conducted in two steps: Cattle adaptation and data collection. Cattle adaptation was carried out for 2 weeks, and the cattle were fed the experimental feed. The experimental feed was formulated into five combinations: R1 ( $50 \%$ king grass); R2 ( $12.5 \%$ corn stover $+7.5 \%$ king grass $50 \%$ concentrate); R3 ( $25 \%$ corn stover $+25 \%$ king grass); R4 (37.5\% corn stover $+12.5 \%$ king grass); and R5 (50\% corn stover). All experimental feeds were added with $50 \%$ concentrate. Data were collected in five intervals, and each interval was of 4 weeks. In every interval, weight gain and digestibility were measured every day, beginning from the $4^{\text {th }}$ week by collecting feces. Dry matter (DM), organic matter $(\mathrm{OM})$, crude protein $(\mathrm{CP})$ digestibility, neutral detergent fiber (NDF), acid detergent fiber (ADF), body weight gain, and feed conversion data were analyzed.
\end{abstract}

Results: R4 and R5 treatment significantly increased $(p<0.05)$ the feed nutritional value and weight gain of male Ongole steer calves. Interestingly, treatment with $\mathrm{R} 4$ had the maximum increase $(\mathrm{p}<0.05)$ on the digestibility value of each variable: DM, 68.85\%; OM, 71.89\%; CP, 73.90\%; NDF, 59.10\%; ADF, 55.35\%; and weight gain, 0.61/gr/day.

Conclusion: R4 treatment found to be the best nutritional value for improving the productivity of male Ongole steer calves.

Keywords: complete feed, corn stover, king grass, Ongole breed.

\section{Introduction}

Corn stover consists of stalk, leaves, cob, and flower of corn left in the field after harvesting on the $45^{\text {th }}-46^{\text {th }}$ day after their plantation [1]. Corn stover contains slightly more crude protein (CP) $(12.06 \%)$, crude fiber (CF) (25.02\%), and a net energy content of 2350 $\mathrm{Kcal} / \mathrm{kg}$ [2]. Furthermore, corn stover also contains $91.94 \%$ dry matter (DM), $43.23 \%$ organic matter $(\mathrm{OM})$, 94\% lignin, $4.95 \%$ silica, $68.78 \%$ neutral detergent fiber (NDF), and $42.36 \%$ acid detergent fiber (ADF). The digestibility of DM and OM of corn stover, which ranges from $59.48 \%$ to $88.71 \%$, is considerably higher when compared with other fodders [3]. Supplementation with by-products of local crops such as rice bran and legume leaves increases feed intake and digestibility. Corn stover without supplementation has been reported to increases cattle weight by $0.55 \mathrm{~kg} / \mathrm{cow} / \mathrm{day}$, whereas supplementation with rice bran and legume leave increases it by $0.77 \mathrm{~kg} / \mathrm{cow} /$ day $[4,5]$.

Copyright: Tuturoong, et al. Open Access. This article is distributed under the terms of the Creative Commons Attribution 4.0 International License (http://creativecommons.org/licenses/ by/4.0/), which permits unrestricted use, distribution, and reproduction in any medium, provided you give appropriate credit to the original author(s) and the source, provide a link to the Creative Commons license, and indicate if changes were made. The Creative Commons Public Domain Dedication waiver (http:// creativecommons.org/publicdomain/zero/1.0/) applies to the data made available in this article, unless otherwise stated.
Another valuable forage for ruminants is the king grass (Pennisetum purpupoides). It possesses high protein content and palatability [6]. King grass has been grown in many locations and has been tested in many laboratories. King grass contains $11.88 \% \mathrm{CP}, 25.48 \%$ $\mathrm{CF}$, and a net energy content of $2070 \mathrm{kcal} / \mathrm{kg}$ [2], $59.7 \%$ of NDF, $0.7 \%$ calcium, and $57 \%$ total digestible nutrition [7]. King grass has digestibility values in the range of $56.27-87.85 \%$. Ongole is the most favored cattle breed of local farmers in Indonesia. It is a crossbreed between Ongole from India and the local cattle from Java [8]. Ongole breed has long been adapted in Indonesia, especially in North Sulawesi. Ongole breeds are reared to serve dual purposes of beef cattle and working cattle. Ongole breed has also been proven to possess resistance to cow parasites, high temperature, and displays higher tolerance to high-fiber feed [9].

The highest digestibility of $\mathrm{DM}$ and $\mathrm{OM}$ of corn stover and king grass in the Ongole breed was obtained by a combination of $75 \%$ corn stover and $25 \%$ king grass that contributed to weight gain up to $3,600,372 \mathrm{~g} / \mathrm{cow} /$ day [3]. However, no data are available for the combination of corn stover and king grass supplemented with concentrated still. Therefore, this study aimed to assess the effect of a combination of corn stover and king grass supplemented with concentrate on Ongole breed productivity. 


\section{Materials and Methods}

\section{Ethical approval}

Ethical approval was not required for this study.

\section{Study design}

This study used a $5 \times 5$ Latin square design, according to Steel and Torrie [10]. It was carried out in the following stages:

1. Preliminary stage

Before conducting the study, the animals were placed randomly in the experimental cage. They were adapted to the cage and fed with experimental feed (a combination of corn stover and king grass). Feed adaptation was carried out for 14 days. Feeds were given ad libitum, and drinking water was provided at all times.

2. The pre-collection stage was carried out 7 days before data collection. A feeding limit of $85 \%$ established in the preliminary stage. Feed restriction was performed to maximize feed intake.

3. The collection phase was carried out for 14 days for every period (for five periods).

4. The resting period was carried out for 14 days. Livestock were given treatment feed to adapt them to the treatment feed and to nullify the effects of the previous period.

Weight gain measurements were taken in every stage, whereas digestibility was measured every day, beginning from the $4^{\text {th }}$ week, by collecting the feces. This study aimed to determine feed formulation from a combination of two feed sources (corn stover and king grass) in complete feed. Thus, the treatment (R1$\mathrm{R} 5$ ) is a comparison/combination of two feed sources, and it does not include controls. In this study, various treatments (combinations) were compared to determine the best formulation.

\section{Animals and feeding treatment}

Twenty-five Ongole male calves aged 26 months and weighing 220-245 kg were included. Livestock were placed individually in a metallic cage. The effect of corn stover and king grass feed supplemented with concentrate was evaluated by comparing it with complete feed contained isoprotein (13-14\%). Proximate analysis of the nutrient content of the feed ingredients used in this study is presented in Table-1, while the formulation and composition of corn stover and king grass feed and complete feed are presented in Table- 2 .

\section{Evaluation of digestibility}

The chemical composition of corn stover and king grass was analyzed using a standard procedure for DM according to the AOAC procedure [11]. NDF, ADF, cellulose, hemicellulose, and total lignin were measured according to Van Soest et al. [12]. Feed consumption was calculated using the following formula:

$$
\begin{aligned}
& \text { Dry matter intake }(\mathrm{DMI})=\text { Total feed }(\mathrm{g}) \times \\
& \% \text { dry matter }- \text { remaining } \mathrm{DM}(\mathrm{g}) \times \% \mathrm{DM}
\end{aligned}
$$

Organic matter intake $(\mathrm{OMI})=$ Total DM $(\mathrm{g}) \times$

$$
\begin{aligned}
& \% \mathrm{OM}-\text { remaining } \mathrm{DM}(\mathrm{g}) \times \% \mathrm{OM} \\
& \text { Crude protein intake }(\mathrm{CPI})=\text { Total } \mathrm{DM}(\mathrm{g}) \times \\
& \% \mathrm{CP}-\text { remaining } \mathrm{CP}(\mathrm{g}) \times \% \mathrm{CP}
\end{aligned}
$$

Digestibility of corn stover and king grass was (3) sured according to Tilley and Terry [13]:

Dry matter

Digestibility $=\frac{\text { DMI }- \text { Dry matter od feses }}{\text { DMI }} \times 100$

(DMD)

Organic matter

Digestibility $=\frac{\text { OMI }- \text { organic matter of feses }}{\text { OMI }} \times 100$

(OMD)

Crude protein

Digestibility $=\frac{\mathrm{CPI}-\text { crude protein of feses }}{\mathrm{CPI}} \times 100$

(CPD)

Body weight gain (BWG) was measured, according to Tillman et al. [14]. BWG was obtained by subtracting the initial body weight from the weight of the cattle at the end of the treatment, the feed collection period. Daily weight gain was calculated by multiplying BWG by the total number of observations. Metabolic weight was also calculated by weighing feces and urine at the beginning of the collection period.

\section{Statistical analysis}

Data were analyzed using one-way analysis of variance, which performed with the SPSS for

Table-1: Feeding concentration used in this study.

\begin{tabular}{lccc}
\hline Nutrient & Concentrate (\%) & Corn stover (\%) & King grass (\%) \\
\hline Dry matter & 88.14 & 23.30 & 22.20 \\
Protein & 17.69 & 10.55 & 9.70 \\
Crude fat & 10.78 & 1.90 & 2.00 \\
Crude fiber & 11.25 & 28.70 & 36.10 \\
NDF & 27.30 & 63.20 & 71.10 \\
ADF & 14.42 & 31.30 & 41.90 \\
Ca & 0.73 & 0.36 & 0.36 \\
P & 1.82 & 0.21 & 0.29 \\
Gross energy (Kcal) & 3708.89 & 4346.16 & 4158.70 \\
\hline
\end{tabular}

$\mathrm{NDF}=$ Neutral detergent fiber, $\mathrm{ADF}=$ Acid detergent fiber, $\mathrm{Ca}=$ Calcium, $\mathrm{P}=$ Phosphorus

Veterinary World, EISSN: 2231-0916 
Windows (IBM Corp., USA). Significance of difference between all treatment groups was indicated by $\mathrm{p}<0.05$.

\section{Results}

The evaluation of the digestibility value of DM, $\mathrm{OM}, \mathrm{CF}$, cellulose, and hemicellulose of corn stover and king grass in complete feed on organochlorine (OC) cattle is presented in Table-3.

\section{DM digestibility (DMD)}

The results showed that the DMD of feed comprising of corn stover and king grass in this study ranges from $65.95 \%$ to $68.85 \%$. Analysis of variance showed a significant difference $(\mathrm{p} \leq 0.05)$. The highest digestibility was found with R4 treatment (68.85\%), which included a combination of feed containing $37.5 \%$ corn stover $+12.5 \%$ king grass $+50 \%$ concentrate. R 5 treatment also showed similar results (DMD $-68.70 \%$ ), with complete feed containing $50 \%$ corn stover, $0 \%$ king grass, and $50 \%$ concentrate. The DMD values were higher than those obtained with R1, R2, and R3 treatments, which included complete feed containing $0.25-25 \%$ corn stover, $25-50 \%$ king grass, and $50 \%$ concentrate, respectively. The increase in digestibility of DM feed seems proportional to the increasing amounts of corn stover in the complete feed. Data from the proximate analysis (Table-1) showed that the metabolic energy content of corn stover was higher $(4346.16 \mathrm{kcal})$ than that of king grass $(4158.70 \mathrm{kcal})$.
The high metabolic energy content of corn stover was due to the presence of readily available carbohydrates (RACs).

\section{OM digestibility (OMD)}

The average OMD of complete feed was observed to be between $67.98 \%$ and $71.89 \%$. Analysis of variance showed a significant difference $(p \leq 0.05)$. The highest average OMD was observed with R4 treatment $(71.89 \%)$, which was not significantly different from that with R5 treatment $(71.72 \%)$ but was significantly higher than that with R1, R2, and R3 treatments. The lowest OMD was significant $(\mathrm{p}=0.05)$ with R1 (67.78\%) followed by that with R2 and R3.

\section{CP digestibility (CPD)}

The average CPD in complete feed was observed to be between $70.90 \%$ and $73.90 \%$. Analysis of variance showed a significant difference $(\mathrm{p} \leq 0.05)$. R4 and $\mathrm{R} 5$ showed no significant difference ( $>0.05)$, but $\mathrm{R} 1$, $\mathrm{R} 2$, and R3 were significantly different $(\mathrm{p}<0.05)$ from R4 and R5. The highest digestibility was observed with R4 (73.90\%), which included complete feed containing $37.5 \%$ corn stover, $12.5 \%$ king grass, and $50 \%$ concentrate, and the lowest digestibility was observed with R1 (70.90\%), which included complete feed with $0 \%$ corn stover, $50 \%$ king grass, and $50 \%$ concentrate.

The CPD followed the pattern of DM and OMD. The digestibility of $\mathrm{CP}$ in the treatment feed significantly increased with the proportion of corn stover in the complete feed. The increase in DMD was due

Table-2: Feeding formulation used in this study.

\begin{tabular}{|c|c|c|c|c|c|}
\hline \multirow[t]{2}{*}{ Feed combination } & \multicolumn{5}{|c|}{ Treatment } \\
\hline & $\mathbf{R 1}$ & $\mathbf{R 2}$ & $\mathbf{R 3}$ & R4 & $\mathbf{R 5}$ \\
\hline Corn stover & 0 & 12.5 & 25 & 37.5 & 50 \\
\hline King grass & 50 & 37.5 & 25 & 12.5 & 0 \\
\hline Concentrate & 50 & 50 & 50 & 50 & 50 \\
\hline \multicolumn{6}{|c|}{ Feeding composition } \\
\hline Dry matter & 55.07 & 55.23 & 55.39 & 55.57 & 55.72 \\
\hline Organic matter & 43.60 & 44.61 & 45.63 & 46.65 & 47.65 \\
\hline Protein & 13.70 & 13.80 & 13.91 & 14.01 & 14.12 \\
\hline Crude fat & 6.39 & 6.38 & 6.36 & 6.35 & 6.34 \\
\hline Crude fiber & 23.68 & 22.75 & 21.83 & 20.90 & 19.98 \\
\hline NDF & 49.20 & 48.21 & 47.22 & 46.24 & 45.25 \\
\hline ADF & 28.16 & 26.84 & 25.51 & 24.19 & 22.86 \\
\hline Ash & 11.47 & 10.62 & 9.77 & 8.92 & 8.07 \\
\hline Gross energy (Kcal) & 2950.35 & 2967.92 & 2985.49 & 3003.07 & 3020.64 \\
\hline
\end{tabular}

$\mathrm{NDF}=$ Neutral detergent fiber, $\mathrm{ADF}=$ Acid detergent fiber

Table-3: Formulation of feed treatment and composition of feed substances.

\begin{tabular}{lccccc}
\hline Formulation of research feed substance & \multicolumn{3}{c}{ Treatment } \\
\cline { 2 - 5 } & $\mathbf{R 1}$ & $\mathbf{R 2}$ & $\mathbf{R 3}$ & $\mathbf{R 4}$ & $\mathbf{R 5}$ \\
\hline Dry matter digestibility (DMD g) & $65.95^{\mathrm{a}}$ & $66.58^{\mathrm{a}}$ & $66.90^{\mathrm{a}}$ & $68.85^{\mathrm{b}}$ & $68.70^{\mathrm{b}}$ \\
Organic matter digestibility (OMD g) & $67.98^{\mathrm{a}}$ & $68.90^{\mathrm{a}}$ & $70.00^{\mathrm{a}}$ & $71.89^{\mathrm{b}}$ & $71.72^{\mathrm{b}}$ \\
Crude protein digestibility (CPD g) & $70.90^{\mathrm{a}}$ & $71.98^{\mathrm{a}}$ & $73.02^{\mathrm{a}}$ & $73.90^{\mathrm{b}}$ & $73.86^{\mathrm{b}}$ \\
NDF digestibility & $57.75^{\mathrm{a}}$ & $57.85^{\mathrm{a}}$ & $58.15^{\mathrm{a}}$ & $59.10^{\mathrm{b}}$ & $59.08^{\mathrm{b}}$ \\
ADF digestibility & $51.70^{\mathrm{a}}$ & $52.65^{\mathrm{a}}$ & $53.25^{\mathrm{b}}$ & $55.35^{\mathrm{b}}$ & $55.20^{\mathrm{b}}$ \\
Body weight gain & $0.49^{\mathrm{a}}$ & $0.53^{\mathrm{a}}$ & $0.55^{\mathrm{a}}$ & $0.61^{\mathrm{b}}$ & $0.59^{\mathrm{b}}$ \\
\hline
\end{tabular}

Different letter in the same row shows significant difference $(\mathrm{p} \leq 0.05)$. NDF=Neutral detergent fiber, ADF=Acid detergent fiber 
to the higher metabolic energy content of corn stover compared to that of the king grass. Corn stover has kernels rich in RAC.

\section{NDF}

The average NDF digestibility in this study ranged from $57.75 \%$ to $59.10 \%$. Analysis of variance showed that the treatment had a significant effect $(p<0.05)$ on the NDF digestibility in complete feed that included corn stover and king grass. The highest NDF digestibility was found with R4 (59.10\%), with complete feed containing $37.5 \%$ corn stover, $12.5 \%$ king grass, and $50 \%$ concentrate and was significantly different $(\mathrm{p}<0.05)$ as compared to that with R1, R2, and R3, but not with R5. The lowest NDF digestibility was observed with R1 (57.74\%). The difference in $\mathrm{NDF}, \mathrm{CP}, \mathrm{CF}$, and energy content between corn stover and king grass in complete feed caused the variability in NDF digestibility. Table- 1 shows that the CF content of corn stover is lower $(28.70 \%)$ as compared to that of king grass $(36.10 \%)$ and that the NDF content in corn stover $(63.20 \%)$ is lower than that of king grass $(71.10 \%)$. In contrast, the CP content in corn stover was higher $(10.55 \%)$ than that of king grass $(9.70 \%)$, and the metabolic energy content of corn stover $(4346.16 \mathrm{Kcal})$ is higher than that of king grass (4158.70 Kcal).

\section{ADF digestibility}

ADF digestibility is determined by the microbial population and cellulolytic microbial activity in the rumen. ADF has the same digestibility pattern as NDF because both have almost the same fiber component. ADF consists of cellulose, lignin, and silicates without hemicellulose and only dissolves in acidic solvents. On the other hand, NDF dissolves in neutral solvents and contains hemicellulose, which can be easily digested. In this study, the average ADF digestibility of complete feed that comprised of corn stover and king grass ranged from $51.70 \%$ to $55.35 \%$ and was lower than NDF digestibility (57.74\%-59.10\%).

\section{BWG}

The BWG of complete feed comprising of corn stover and king grass for each calf ranged from 0.49 to $0.61 / \mathrm{gr} / \mathrm{day}$. Analysis of variance showed a significant difference $(p \leq 0.05)$. The highest increase was observed with R4 (0.61/gr/day). R5 led to a non-significant decrease $(0.59 / \mathrm{gr} /$ day $)$ and a significant increase was observed with R1, R2, and R3 treatments. The lowest BWG was observed with R1 (0.49/gr/day) with a complete feed formulation of $50 \%$ king grass and $50 \%$ concentrate without the administration of corn stover followed by R2 (0.53/gr/day) and R3 (0.55/gr/ day).

\section{Discussion}

The study showed that the average proportion of young kernels in corn stover was $17 \%$. This readily digested carbohydrate can serve as an energy source for optimal rumen microbial development. The availability of RAC spurs rumen microbial growth so that it has a positive impact on increasing the DMD. In the rumen, the microbial process of degradation of proteins obtained from the feed is faster than the process of providing energy (resulting into formation of ammonium, which can be used as a source of nitrogen), so the presence of corn stover-based RAC increases the efficiency of rumen microbial protein synthesis.

The study conducted by Nasriya et al. [3] reported that the average level of corn stover digestibility as a single feed source in OC calves reached $59.48 \%$, and the DMD of king grass as a single feed was $56.27 \%$. Compared with the results of this study, we observe that the digestibility of corn stover as a single forage source with a proportion of $50 \%$ in complete feed (R5) is higher $(68.70 \%)$. On the other hand, the digestibility of king grass as a single forage source, with a proportion of $50 \%$ in complete feed (R1) reached $65.95 \%$. The highest digestibility was found in complete feed with a proportion of $37.5 \%$ corn stover, $12.5 \%$ king grass, and $50 \%$ concentrate (R4). The high digestibility of R4 was due to the complementary factor of the combination of corn stover and king grass in complete feed.

The effect of the treatment on the digestibility of feed OM increased in line with the increasing proportion of corn stover in complete feed. The data revealed that the protein and energy content of corn stover were higher than those observed for the king grass. Feed protein is degraded into ammonia by rumen microbes as a nitrogen source, and they also require energy [15]. The synthesis rate of rumen microbes was positively correlated with the availability of RAC. We also observed an increase in the digestibility of organic materials. Preston and Leng [16] mentioned that when the protein content in feed is low, it reduces the ammonia concentration in the rumen, resulting in slow growth of rumen microbes and inhibition of car-bohydrate degradation.

Protein from feed undergoes degradation into ammonia by rumen microbes as a source of nitrogen for rumen microbes. The degradation rate of protein from feed is determined by the availability of metabolic energy from the feed consumed. The higher the energy obtained from the easily digested carbohydrates, the higher the protein digestibility. CP from feed is degraded by rumen microbes into amino acids and then undergoes deaminase into ammonia as a source of nitrogen and carbon skeleton $(\alpha$-keto) for rumen microbial growth. The higher $\mathrm{CP}$ in the feed consumed, the higher the protein to be degraded to ammonia in the rumen.

Rumen microbes digest NDF more easily than ADF because NDF consists of ADF and hemicellulose, which are easier to be digested by rumen microbes while ADF has no hemicellulose [15]. The level of NDF digestibility in the rumen is affected by the number of fiber-digesting microbial populations 
in the rumen. Protein from feed is not used directly by rumen microbes but is hydrolyzed by rumen microbes into amino acids and subsequently into ammonia as a source of nitrogen for microbial growth. The utilization effectiveness of protein from feed as a source of nitrogen for microbial growth depends on the availability of energy provided that the carbohydrates are easily digested [17]. The higher the CP and energy and the availability of RAC from feed in the rumen, the higher the rate of growth of the rumen microbial population. The high protein and energy content, as well as the presence of corn kernels as the source of RAC in corn stover compared to king grass, are the reason for the high digestibility of NDF following treatment with $\mathrm{R} 4$ and R5. When the CP content in feed is low, the rumen ammonia concentration is low, so rumen microbial growth is slow; consequently, carbohydrate degradation is delayed. Astuti [9] reported that, in regression, there was a relationship between NDF digestibility and CP content in OC calves feed. NDF digestibility is higher in feed with low fiber content than in high feed [16].

The degradation rate of NDF in the rumen was higher than the degradation rate of ADF [18]. The results are shown in Table-3. The highest ADF digestibility was observed with R4 (55.35\%), complete feed containing $37.5 \%$ corn stover, $12.5 \%$ king grass, and $50 \%$ concentrate, and the lowest was with R1 $(51.70 \%)$, complete feed containing $0 \%$ corn bees, $50 \%$ king grass, and $50 \%$ concentrate. R 1 digestibility was not significantly different from R2 and R3, but significantly different from R4 and R5, whereas R4 digestibility was not significantly different $(\mathrm{p}>0.05)$ when compared with R5. Astuti [9] reported that the lag time needed by rumen microbes to colonize and initiate digestion of forage in the rumen in NDF was faster $(0.7 \mathrm{~h})$ than $\operatorname{ADF}(0.9 \mathrm{~h})$, and NDF degradation rate was higher $(3.4 \% / \mathrm{h})$ compared to $\operatorname{ADF}(2.9 / \mathrm{h})$. We conclude that the values of ADF are inversely proportional to the digestibility.

The higher average BWG after the treatment of complete feed based on corn stover compared with one being treated with complete feed based on king grass was due to the high digestibility of DM, OM, $\mathrm{CP}, \mathrm{NDF}$, and ADF on corn stover-based complete feed [19]. This trend of weight gain was in line with the digestibility levels of $\mathrm{DM}, \mathrm{OM}, \mathrm{CP}, \mathrm{NDF}$, and $\mathrm{ADF}$. The rate of weight gain of cattle is strongly influenced by the digestibility value of the feed consumed. There was a positive correlation between digestibility and weight gain. The level of nutrient digestibility was directly proportional to BWG; the higher the digestibility value of feed, the higher the rate of cattle BWG $[15,20]$.

The increase in BWG was affected by the increase in the proportion of corn stover, which had better nutrient quality than king grass. A complementary effect was observed when king grass was added, which then tended to decrease with R5, although not significantly; hence, there was no complementary effect. Data from the proximate analysis (Table-1) show that the metabolic energy content of corn stover is higher $(4346.16 \mathrm{kcal})$ than that of king grass $(4158.70 \mathrm{kcal})$. The proportion of corn kernels from the total weight of corn stover is approximately $17 \%$. Corn kernels contain RAC for optimal rumen microbial growth.

The availability of this RAC spurs rumen microbial growth; therefore, it has a positive impact on increasing the digestibility of feed nutrients [21]. The higher the digestibility of feed nutrients, the higher the feed nutrient is converted to BWG [22]. The CP content of corn stover was $10.55 \%$, which was higher than that of king grass $(9.70 \%)$. In contrast, the CF of corn stover was 28.78 and that of king grass was 36.10 and ADF of corn stover was $31.30 \%$, which was lower than the ADF of king grass (41.90\%). According to Tuturoong [17], the higher the CF and ADF content in the forage feed, the higher the content of lignocellulose, especially lignin, thus the more difficult to digest. The rate of weight gain in cattle is influenced by genetic and environmental factors. The average BWG of each local OC calve from Java and Sumba aged 6 months, which was given the king grass ad libitum and concentrate of $3 \mathrm{~kg} / \mathrm{day}$, was $0.51-0.62 \mathrm{~kg} / \mathrm{day}$, which was lower than the weight gain of local OC cattle (Javanese and Sumba cattle) crossed with imported cows (Simmental breeds), which was $0.71 \mathrm{~kg}$.

\section{Conclusion}

Based on the results of this study, we conclude that the corn waste- and king grass-based feed $(37.5 \%$ corn waste formulation, $12.5 \%$ king grass, and 50\% concentrates) provided best nutritional value for local Ongole crossbred calves.

\section{Authors' Contributions}

RAVT designed and conducted the experiment, acquisition of data, and drafting of the manuscript. SSM conducted the experiment and collected the data. SAEM analyzed the data and drafting the manuscript. All authors read and approved the final manuscript.

\section{Acknowledgments}

The authors thank Indonesian Ministry of Research Technology and Higher Education and Sam Ratulangi University, for providing necessary facilities for this research. This research was funded by the Directorate General of Research and Development Strengthening, Ministry of Research Technology and Higher Education, Indonesia, with grant no. 240/ UN12.13/LT/2019.

\section{Competing Interests}

The authors declare that they have no competing interests. 


\section{Publisher's Note}

Veterinary World remains neutral with regard to jurisdictional claims in published institutional affiliation.

\section{References}

1. Garlock, R.J., Chundawat, S.P., Balan, V. and Dale, B.E. (2009) Optimizing harvest of corn stover fractions based on overall sugar yields following ammonia fiber expansion pretreatment and enzymatic hydrolysis. Biotechnol. Biofuels, 2(2009): 29-38.

2. Erna, W. and Sarjiman, S. (2007) Budidaya hijauan pakan bersama tanaman pangan sebagai upaya penyediaan hijauan pakan di lahan sempit. J. Peternakan dan Lingkungan, 7(2007): 134-141.

3. Nasriya, N., Victor, T.R.A., Kaunang, C.L., Malalantang, S.S. and Tindangen, M.M. (2016) Pengaruh pemberian rumput raja (Pennisetum purpoides) dan tebon jagung terhadap kecernaan bahan kering dan bahan organik pada sapi PO. Zootec, 36(2): 387-394.

4. Marsetyo, M., Damry, D. and Mustaring, M. (2015) The effect of supplementation of Gliricidia or rice bran on live weight gain, feed intake and digestibility of Kacang goat fed Mulato grass. The $6^{\text {th }}$ International Seminar on Tropical Animal Production Integrated Approach in Developing Sustainable Tropical Animal Production, Yogyakarta, Indonesia.

5. Quang do, V., Ba, N.X., Doyle, P.T., Hai, D.V., Lane, P.A., Malau-Aduli, A.E., Van, N.H. and Parsons, D. (2015) Effect of concentrate supplementation on nutrient digestibility and growth of Brahman crossbred cattle fed a basal diet of grass and rice straw. J. Anim. Sci. Technol., 57(2015): 35.

6. Li, H.Y., Xu, L., Liu, W.J., Fang, M.Q. and Wang, N. (2014) Assessment of the nutritive value of whole corn stover and its morphological fractions. Asian Aust. J. Anim. Sci., 27(2): 194-200.

7. Sutardi, T. (1981) Sapi Perah dan Pemberian Makanannya Fakultas Petemakan Institut Pertanian Bogor, Bogor

8. Mohamad, K., Olsson, M., van Tol, H.T., Mikk, O.S., Vlamings, B.H., Andersson, G., Rodríguez-Martínez, H., Purwantar, A.B., Paling, R.W., Colenbrander, B. and Lenstra, J.A. (2009) On the origin of Indonesian cattle. PLoS One, 4(5): e5490.

9. Astuti, M. (2005) Potensi dan Keragaman Sumber Daya Genetik Sapi Peranakan Ongole (PO). Wartozoa, 15(1): 98-106.

10. Steel, R.G.D. and Torrie, J.H. (1993) Prinsip dan Prosedur Statistika (Pendekatan Biometrik) Penerjemah B. Sumantri. Gramedia Pustaka Utama, Jakarta.

11. Official Methods of Analysis. (2005) Determination of Water/Dry Matter (Moisture) in Animal Feed, Grain, and
Forage (Plant Tissue). Association of Official Analytical Chemists, Arlington, VA, USA.

12. Van Soest, P.J., Robertson, J.B. and Lewis, B.A. (1991) Methods for dietary fiber, neutral detergent fiber, and nonstarch polysaccharides in relation to animal nutrition. $J$. Dairy Sci., 74(10): 3583-3597.

13. Tilley, J.M.A. and Terry, R.A. (1963) A two stage technique for in vitro digestion of forage crop. J. Brit. Grassland Soc., 18(2): 104-114.

14. Tillman, A.D., Hartadi, H., Reksohadiproko, S., Prawirokusumo, S. and Lebdosoekodjo, S. (2001) Ilmu Makanan Ternak Dasar. Gadjah Mada University Press, Yogyakarta.

15. Tuturoong, R.A.V. (2016) Metode Pembuatan Pakan Komplit Ternak Ruminansia Berbasis Rumput Benggala Teramoniasi dan Ampas Sagu Terermentasi. Directorate General of Intellectual Property Ministry of Law and Human Rights (HAKI) RI, Jakarta.

16. Preston, T.R. and Leng, R.A. (1987) Matching Ruminant Production Systems with Available Resources in the Tropic and Sub-tropic. Penambul Books, Stanthorpe, Queensland, Australia.

17. Tuturoong, R.A.V. (2013) Nutritive Evaluation of Ammoniated Benggala Grass and Fermented Sago Waste. University of Agronomic Sciences and Veterinary, Bucharest.

18. Keim, J.P., Valderrama, X., Alomar, D. and López, I.F. (2013) In situ rumen degradation kinetics as affected by type of pasture and date of harvest. Sci. Agric., 70(6): 405-414.

19. Gebrehawariat, E., Berhan, T. and Azage, T. (2010) Feed intake and production parameters of lactating crossbred cows fed maize-based diets of stover, silage or quality protein silage. Trop. Anim. Health Prod., 42(8): 1705-1710.

20. Sath, K., Sokun, K., Pauly, T. and Holtenius, K. (2010) Feed intake, digestibility, and $\mathrm{N}$ retention in cattle fed rice straw and para grass combined with different levels of protein derived from cassava foliage. Asian Aust. J. Anim. Sci., 25(7): 956-961.

21. Thien, T.G.N., Metha, W., Kampanat, P. and Sungchhang, K. (2017) Effect of inclusion of different levels of Leucaena silage on rumen microbial population and microbial protein synthesis in dairy steers fed on rice straw. Asian Aust. $J$. Anim Sci., 30(2): 181-186.

22. Elham, K., Morteza, C. and Tahereh, M. (2017) Effects of physical form of diet on nutrient digestibility, rumen fermentation, rumination, growth performance and protozoa population of finishing lambs. Anim. Nutr., 3(2): 139-144. 